\title{
Utilization of Glass Waste as Fine Aggregate Replacement and Rice Husk Ash as Cement Replacement in Concrete: A Review
}

\author{
Shahid Ali, SHAIKH \\ Department of Civil Engineering, Mehran University of Engineering and Technology SZAB \\ Khairpur Mir's, 66020 Sindh, Pakistan \\ shahid.huawei155@gmail.com
}

Sajjad Ali, MANGI

Department of Civil Engineering, Mehran University of Engineering and Technology SZAB Khairpur Mir's, 66020 Sindh, Pakistan

Muhammad Nawaz, SAHITO

Department of Civil Engineering, Mehran University of Engineering and Technology SZAB Khairpur Mir's, 66020 Sindh, Pakistan

Naveed Ayoub, GHUMRO

Department of Civil Engineering, Mehran University of Engineering and Technology SZAB Khairpur Mir's, 66020 Sindh, Pakistan

Faheem Ahmed, SOOMRO

Khairpur Medical College, Khairpur Mirs, 66020 Sindh, Pakistan

\begin{abstract}
Cement as a binder used in the mixture of concrete is a costly product and it is also harmful to the environment due to the emission of huge amounts of $\mathrm{CO} 2$ and other gases. Like cement the fine aggregate is also the main constituent of the concrete used as inert filler in concrete is also expensive. The researchers are probing towards the new inexpensive and environment friendly materials for the concrete. They have agreed over the point that by utilizing the recycled waste materials could be helpful in achieving the sustainable construction. So in this case a lot of research has been carried out for the utilization of rice husk ash as cement substitution and recycled waste glass as alternative of concrete fine aggregate. The outcome of this research is that these both green materials have enormous potential to contribute in the long-lasting handling of ineffectual solid waste, reduction of landfill sites, preserving natural resources and protecting atmosphere from extremely hazardous gases. The purpose of this review work is to summarize the previous research findings on utilization of rice husk ash and recycled waste glass as a substitution to the cement and fine aggregate respectively. This review paper will come up with the remarkable idea and valuable information for the upcoming researchers working for the aim of utilization of renewable and futile materials in the field of concrete technology.
\end{abstract}

\section{Keywords}

Waste glass utilization, Glass concrete, fine aggregate replacement, rice husk ash, cement replacement, compressive strength, reduction in cost, improved strength.

\section{Introduction}

We are using modern concrete since middle of the 19th century but as long as two decades researchers have shifted their focus towards the utilization of supplementary pozzolanic products in the concrete. The reason behind shifting of centre of attention is the sustainability of the concrete and cement manufacturing industries. The production of concrete per year is 10 billion cubic meters. The concrete industry is the largest consumer of key building materials such as cement and natural sand. The world's most populated country China only generated around 2.2 billion metric tons and the India another thickly populated country produced around 320 million metric tons in the year 2019 (Morrin 2003). The statics shows that China is producing over half of the world's cement. It is expected that 
the global cement production will touch the land mark of 4.83 billion metric tons in 2030 (Morrin 2003). The production of cement causes emission of carbon dioxide (CO2) (Datis Export Group 2020), an influential greenhouse gas. The production of only one metric ton of ordinary cement emits one metric ton of $\mathrm{CO} 2$. The amount of emission is about $8 \%$ of global $\mathrm{CO} 2$ emissions. According to the Paris Agreement on climate change, the member countries agreed to reduce the annual discharge of CO2 up to $16 \%$ by the year 2030 (IEA 2017). The reduction in emissions of carbon dioxide and construction cost can be possible if some by-products are used in the concrete. One of the major crop of the world is the Rice (Oryza sativa: Scientific name of rice). The global rice production in 2016 would be around 745.5 million tons as shown in figure 1. Major production of rice is in Asia and pacific regions (Datis Export Group 2020). It is around $11 \%$ of the total world's cultivated land. The rice grains are naturally surrounded by a protecting sheath known as hull or husk (Datis Export Group 2020).

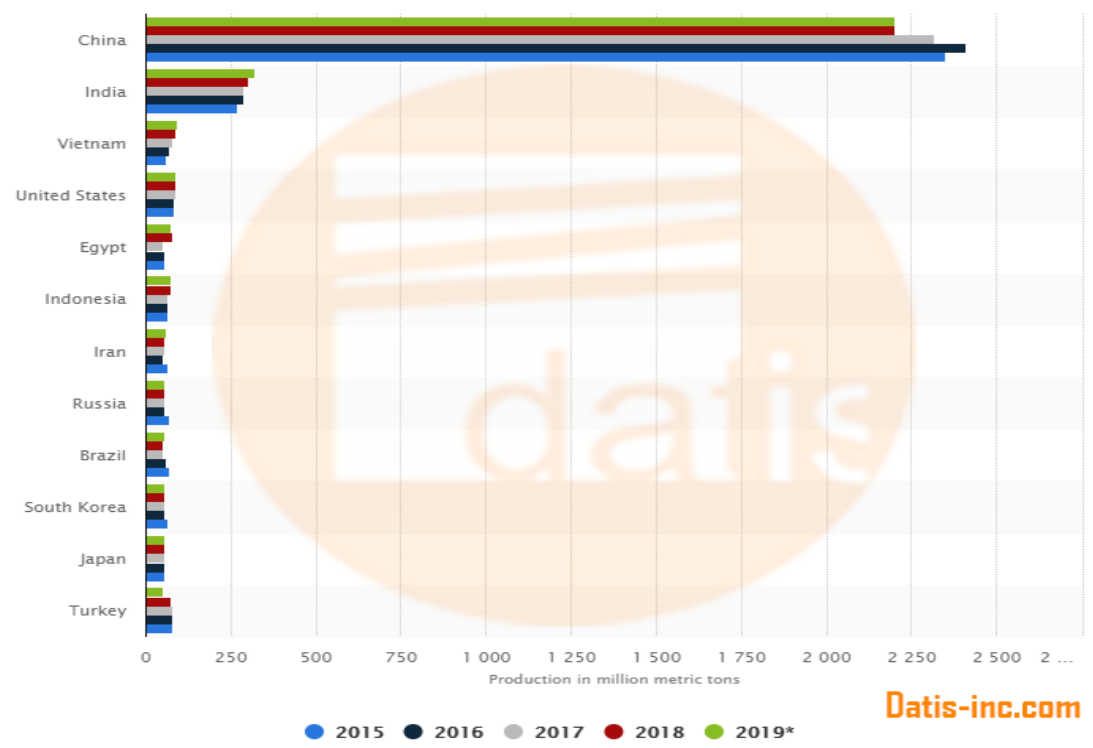

Figure 1 : Worldwide Cement Production from 2015 to 2019-Datis Export Group-Cement Supplier [2]

The world's paddy production in 2018 was forecasted that the global production which has 10.3 million tons annual expansion will touch a peak of 769.9 million tons (510.6 million tons, on milled basis) as shown in figure 2 and 3 (Anand and S 2015).

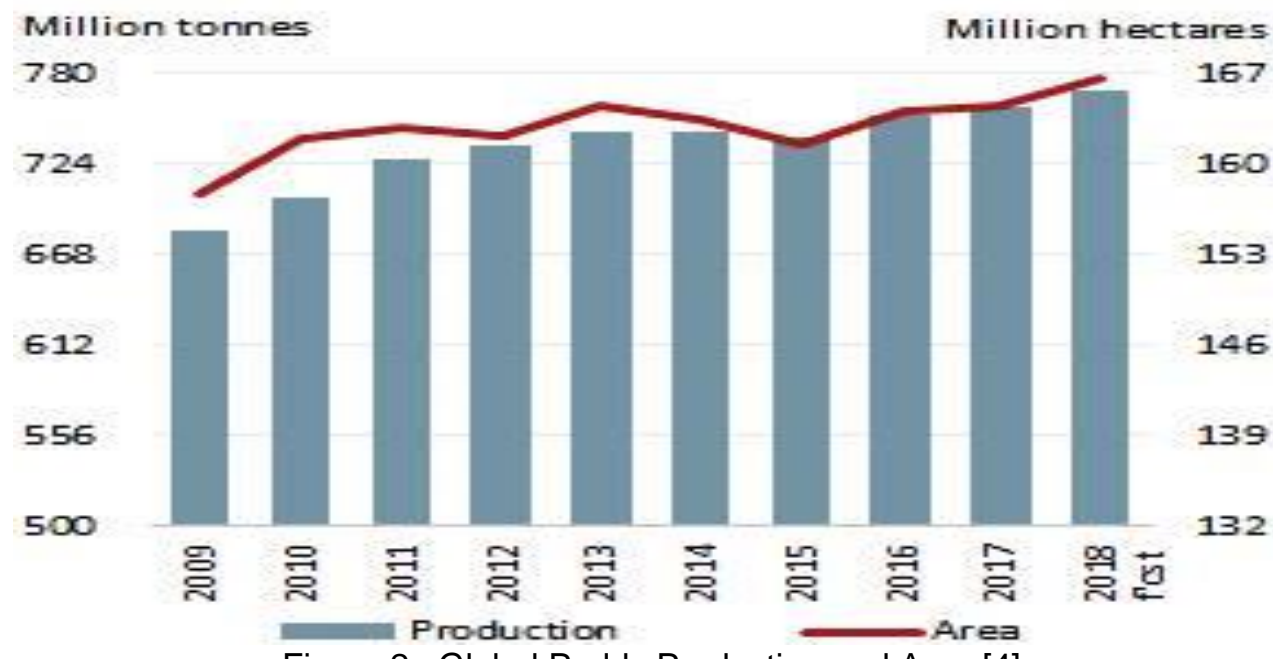

Figure 2 : Global Paddy Production and Area [4] 


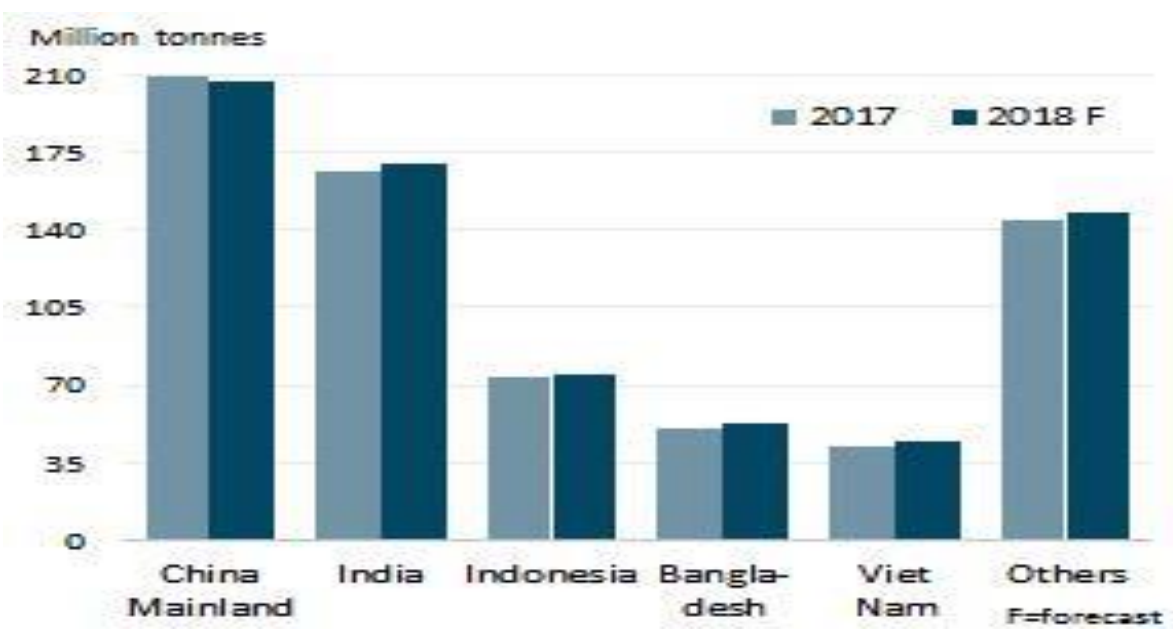

Figure 3 : Paddy production in Asia [4]

\section{Previous Research}

The summary of literature review has been presented in Table 1. It specifies the previous research findings on the incorporation of RHA as cement substitution and RWG as fine aggregate replacement in the concrete. The researchers and scientists have reconnoitered that the RHA has great capability to perform as a Pozzolanic material, it can be assumed as a replacement of cement for the normal and high strength concrete. In the same way it has been analyzed that the concrete prepared with RWG is competent enough to provide long term strength, stability and good thermal insulation. Therefore, acquiring of these both materials can reduce the cost and environmental issues and will provide a sustainable solution to the construction industry.

Table1: Summary of previous research findings

\begin{tabular}{|c|c|c|c|c|c|}
\hline Ref & $\begin{array}{c}\text { Countr } \\
y\end{array}$ & Materials & $\begin{array}{l}\text { Mix Design Proportions \& } \\
\text { Curing }\end{array}$ & Testing & $\begin{array}{l}\text { Key Research } \\
\text { Findings }\end{array}$ \\
\hline [4] & India & $\begin{array}{l}\text { Recycled } \\
\text { Glass Powder } \\
\text { as fine } \\
\text { aggregate }\end{array}$ & $\begin{array}{l}\text { M20 Grade Concrete w/c of } \\
0.5, \text { portion of recycled glass } \\
0 \%, 20 \%, 40 \%, 60 \%, 80 \% \text {, } \\
100 \% \text {, curing period } 28 \\
\text { days, No Chemical } \\
\text { Admixture. }\end{array}$ & $\begin{array}{l}\text { No significant } \\
\text { Variation } \\
\text { High Split Tensile } \\
\text { Strength }(0 \%)\end{array}$ & $\begin{array}{l}\text { No significant } \\
\text { variations found in } \\
\text { mechanical } \\
\text { properties of } \\
\text { concrete. }\end{array}$ \\
\hline [5] & Poland & $\begin{array}{l}\text { Glass waste } \\
\text { from recycled } \\
\text { lighting } \\
\text { material as } \\
\text { aggregate }\end{array}$ & $\begin{array}{l}\text { Cement CEM I } 42,5 \mathrm{~N}-\mathrm{SR} \\
3 / \mathrm{NA} \text {, Portion of recycled } \\
\text { tube light glass } 10 \%, 30 \% \text {, } \\
50 \% \text { and } 100 \% \text {. Fly ash } \\
\text { (Additive) }\end{array}$ & $\begin{array}{l}\text { Compressive strength } \\
31.7 \mathrm{MPa} \\
\text { tensile (flexural ) } \\
\text { strength of } 7.43 \mathrm{MPa}\end{array}$ & $\begin{array}{l}\text { Substituting } 30 \% \\
\text { of recyclable } \\
\text { aggregate makes } \\
\text { a composite } \\
\text { having } \\
\text { Compressive } \\
\text { strength } 31.7 \\
\text { MPa, and tensile } \\
\text { (flexural) strength } \\
\text { of } 7.43 \mathrm{MPa} \text {. } \\
\text { The microscopic } \\
\text { analysis showed } \\
\text { that the flat shape } \\
\text { cause the } \\
\text { accumulation of } \\
\text { air in the concrete. }\end{array}$ \\
\hline [6] & China & $\begin{array}{l}\text { Recycled } \\
\text { Cathode Ray } \\
\text { Tube funnel } \\
\text { glass (fine } \\
\text { aggregate }\end{array}$ & $\begin{array}{l}\text { Portland Cement (P.O } \\
\text { 42.5),(Class F), Fly ash, } \\
\text { Recycled CRT funnel } \\
\text { glass }(4.75 \mathrm{~mm}) \text { with } \\
20 \%, 40 \%, 60 \%, 80 \%, 100 \%, \mathrm{w}\end{array}$ & $\begin{array}{l}\text { Increase in density of } \\
\text { mix, CRT glass mix } \\
\text { concrete has low } \\
\text { water absorption, } \\
\text { tensile and }\end{array}$ & $\begin{array}{l}\text { Densities increase } \\
\text { with increase in } \\
\text { Glass Aggregate, } \\
5.21 \% \text { increase } \\
\text { with GA- } 4.75 \mathrm{~mm}\end{array}$ \\
\hline
\end{tabular}




\section{),OPC, Fly ash ater to binder ratio of .45, curing as per GB/T 50081- 2002 ,}

$\begin{aligned} \text { [7] India } & \text { Discarded } \\ & \text { Beverage } \\ & \text { glass (DBG) } \\ & \text { as fine } \\ & \text { aggregate, }\end{aligned}$

[8] Algeria Cathode Ray

Tube Glass

(CRTG) as

fine aggregate

and

Metakaolin

(MK) as

supplementary

cementitious

material on

the Self

Compacting

Concrete

(SCC)

\begin{tabular}{|c|c|}
\hline [9] India & $\begin{array}{l}\text { Cement, Slag, } \\
\text { Crushed } \\
\text { White Glass } \\
\text { Aggregate(C } \\
\text { WGA), }\end{array}$ \\
\hline
\end{tabular}

PPC Cement $\left(\mathrm{G}_{\mathrm{s}}=3.11\right)$, DBG $\left(\mathrm{G}_{\mathrm{s}}=2.39\right)$ passed $600 \mu$ and retained on $150 \mu$ sieve, Proportions used by wt. $0 \%$, $18 \%, 19 \%, 20 \%, 21 \%, 22 \%$, $23 \%$ and $24 \%$. Use of Scanning Electron Microscopy (SEM), Energy Diffraction X-Ray Analysis (EDAX) performed, Super plasticizer Polycarboxylic ether polymer based. W/c of 0.4 , compaction factor 0.9 .

OPC, Metakaolin(MK) as partial Metakaolin is used as cement replacement $5 \%, 10 \%, 15 \%$ by weight ,Waste CRTG used as replacement of river sand as FA in proportions of $0 \%, 10 \%, 20 \%, 30 \%, 40 \%$ and $50 \%$ by weight, chemical admixture, Two classes of limestone gravel $G 3 / 8$ and $G 8 / 15$ as coarse aggregate with $40 \%$ and $60 \%$ in concrete mixes respectively, super plasticizer Polycarboxylic ether (density 1.07), River sand (Max: size $5 \mathrm{~mm}),(\mathrm{w} / \mathrm{b}=0.4)$, Curing time intervals were 7,28 and 90 days.

M25 grade concrete, OPC, Slag replacement $20 \%$ by weight, CWGA passing

$4.75 \mathrm{~mm}$ and retained $1.18 \mathrm{~mm}$ is partially replaced with river sand from $0 \%, 10 \%, 20 \%, 30 \%, 40 \%$ and $50 \%$ by weight, Coarse Aggregate (passing $20 \mathrm{~mm}$ and retained $12.5 \mathrm{~mm})\left(\mathrm{G}_{\mathrm{s}}=2.75\right)$, PCE(Polycarboxylic ether used as super-plasticizer as water reducer up to $1.5 \%$, compressive strength

with $100 \%$.

and elastic modulus and has low impact on damping.

The workability of

fresh concrete

decrease with

increase in $\mathrm{DBG}$

portion due to sharp

edges. The

compressive strength

has negligible impact

at $21 \%$ replacement.

Flexural Strength

increases. A decrease

in bulk density of DBG

concrete observed.

The water absorption increases.

The compressive

strength and UPV

(Ultra sonic Pulse

Velocity) decreased as

increase in the

percentage of CRTG

in SCC mixture. The

compressive strength

and UPV values

increased by addition

of MK. The

substitution of cement

with $10 \% \mathrm{MK}$ and

sand by $50 \%$ CRTG

portion will increase

the control SCC

mixture by $16 \%$ and

$3 \%$ respectively at 90

days curing. $46 \%$ and

$25 \%$ decrease is

found in porosity and

gas permeability

respectively. The

chloride ion

permeability

resistance is observed

much higher.

The test observations reveals that the

compressive, split and

flexural rigidity has

improved values of strength attainment with the use of $30 \%$ of

CWGA and $20 \%$ of

Slag with $100 \%$ of coarse aggregate.UPV

(Ultrasonic Pulse

Velocity) values lie in

a feasible state between 3.5 and 3.9
As per micro structural analysis there was strong interfacial bonding between cement paste and aggregate. For non-aggressive environment $21 \%$ DWG replacement can be utilized in concrete mix.

Renewable sources have potential to improve the solid waste management while saving landfill sites. Up to $50 \%$ CRTG will increase flow ability of SCC with low SP and low water absorption due to smooth surface of CRTG surface.

The use of CWGA reduces the waste and $\mathrm{CO}_{2}$ emission problems. In addition by using up to $40 \%$ of CWGA increases the consistency in fresh concrete. With $20 \%$ slag in OPC the workability is increased. 
$\mathrm{w} / \mathrm{b}=0.42$

[10] China

OPC, Fly Ash

(class F), Fine

Aggregate

includes

Cathode Ray

Tube Glass

(CRT) and

natural sand,

Coarse

Aggregate

(granite).
Portland Cement (type

42.5N), Fly Ash (Class F),

Fine Aggregate includes

Cathode Ray Tube Glass

(CRT) and natural sand,

Coarse Aggregate (granite max. diameter

$26.5 \mathrm{~mm}$ ), Natural sand is replaced by CRT Glass

having proportions $30 \%, 60 \%$

and $100 \%$ by volume, curing period of 28 days. $\mathrm{km} / \mathrm{sec}$. at different

intervals of moist curing, With the use of UPV the modulus of elasticity of concrete has enhanced and the values reached from $26 \mathrm{MPa}$ to $43 \mathrm{MPa}$.

With a rise in the amount of CRT glass the compressive strength and elastic modulus of concrete mix is decreased. The mix containing CRT glass has more compressive strength than the control concrete under sulphate attack.

\section{[11] Iraq}

[12] Thailan Rice Husk Ash d and Ground Rice Husk Ash (GRHA) as partial replacement to cementitious material in Recycled Aggregate Concrete
OPC, natural sand as fine aggregate (max: size $4.75 \mathrm{~mm}$ of desert origin), coarse aggregate (max: size $20 \mathrm{~mm}$ ) and bulk density $1545 \mathrm{~kg} / \mathrm{m}^{3}$, Crushed Waste Glass (CWG), Two types concrete mixes were prepared, one with natural sand and gravel and the other mix with replacing waste glass as $10 \%, 15 \%$ and $20 \%$ of natural sand, water/cement ratio of 0.53 , Curing period $3,7,14,28$ days.

OPC $\left(G_{s}=3.15\right)$, Ordinary Rice Husk Ash $\left(\mathrm{G}_{\mathrm{s}}=1.89\right)$, $\mathrm{GRHA}\left(\mathrm{G}_{\mathrm{s}}=2.24\right)$ retained on sieve No. 325, Use of GRHA $20 \%$ to $50 \%$ by weight of binder, w/b of 0.45 , curing $7,28,60,90$ days.
The pozzolanic effect of waste glass is more at 28 days curing.

The Compressive and flexural strength is higher at $20 \%$ that was $45.9 \mathrm{MPa}$ with an increase of $4.23 \%$ compared to control mix.

Partial replacement of CWG powder as sand reduces the ASR expansion.

The compressive strength at early ages is less and at later ages at 60 days or more improved at $20 \%$ wt. of GRHA. At incorporating $50 \%$ by wt. GRHA has higher chloride penetration resistance and lowest steel corrosion.
There was a negative impact of lower water absorption and porosity due to CRT of glass on the diffusion of chloride as compared to natural sand. Water cement ratio will increase due to the low water absorption by CRT glass and it causes an increase in porosity of concrete surface layer and start a speedy diffusion rate of chlorine ion penetration. Concrete slump decreases with increase in waste glass content due to shape of CWG powder.

It is observed that the addition of GRHA could apparently improve the steel corrosion and chloride penetration resistance of RAC mix. 


\begin{tabular}{|c|c|c|c|c|c|}
\hline [13] & $\begin{array}{l}\text { Thailan } \\
d[3]\end{array}$ & $\begin{array}{l}\text { Rice Husk } \\
\text { Ash, } \\
\text { Cement }\left(G_{S}=3 \text {. }\right. \\
\text { 14) and soft } \\
\text { clay }\end{array}$ & $\begin{array}{l}\text { Bangkok clay (Gs=2.68) } \\
\text { Curing period } 7,14,28 \text { days. } \\
\text { RHA } 20 \%, 30 \%, 35 \% \text { AND } \\
50 \% \text {. }\end{array}$ & $\begin{array}{l}\text { The rice husk ash } \\
\text { exhibits higher } \\
\text { efficiency at the time } \\
\text { when the mixture } \\
\text { contains not less than } \\
20 \% \text { and } 35 \% \text { cement } \\
\text { and cementitious } \\
\text { contents respectively. }\end{array}$ & $\begin{array}{l}\text { As per this paper it } \\
\text { is researched that } \\
\text { the GRHA could } \\
\text { be beneficial when } \\
\text { added in cement } \\
\text { to enhance its } \\
\text { strength } \\
\text { properties. }\end{array}$ \\
\hline [14] & Benin & $\begin{array}{l}\text { Rice Husk, } \\
\text { CEM II B-LL } \\
\text { 32.5 R type } \\
\text { cement }\end{array}$ & $\begin{array}{l}\text { Rice Husk, CEM II B-LL } 32.5 \\
\text { R type cement }\end{array}$ & $\begin{array}{l}\text { The material has good } \\
\text { mechanical behaviour } \\
\text { in terms of } \\
\text { compression and } \\
\text { tensile and thermal } \\
\text { characteristics. }\end{array}$ & $\begin{array}{l}\text { It has been } \\
\text { disclosed through } \\
\text { compatibility study } \\
\text { of this paper that } \\
\text { the rice husk ash, } \\
\text { although not } \\
\text { preheated, is } \\
\text { compatible with } \\
\text { CEM II B-LL } 32.5 \\
\text { R cement. }\end{array}$ \\
\hline [15] & $\begin{array}{l}\text { Thailan } \\
\text { d }\end{array}$ & $\begin{array}{l}\text { Rice Husk Ash } \\
\text { (RHA), } \\
\text { Recycled } \\
\text { Aggregate } \\
\text { Geo-polymer } \\
\text { Concrete } \\
\text { (RAGC's) } \\
\text { High Calcium, } \\
\text { Limestone, Fly } \\
\text { Ash, }\end{array}$ & $\begin{array}{l}\mathrm{RHA}\left(\mathrm{G}_{\mathrm{s}}=2.06\right), \mathrm{Geo}- \\
\text { polymer (green binder used } \\
\text { as substitute to the cement), } \\
\text { Recycled Concrete } \\
\text { Aggregate }(\mathrm{RCA}), \text { Limestone } \\
\text { (Coarse Aggregate), Fly } \\
\text { Ash, Curing Period } 28 \text { and } \\
90 \text { days }\end{array}$ & $\begin{array}{l}\text { The compressive } \\
\text { strength of RAGC's } \\
\text { ranges from } 36.0 \text { to } \\
38.1 \mathrm{MPa} \text { at } 28 \text { days } \\
\text { curing. }\end{array}$ & $\begin{array}{l}\text { Reduction in } \\
\text { strength and } \\
\text { increase in } \\
\text { permeability. } \\
\text { Improves strength } \\
\text { when } \mathrm{SiO}_{2} / \mathrm{Al}_{2} \mathrm{O}_{3} \\
\text { ratio is increased } \\
\text { to } 4.17 \text {. Improve } \\
\text { microstructure and } \\
\text { denser matrix as } \\
\text { comparative to } \\
\text { nano- } \mathrm{SiO}_{2} \text {. }\end{array}$ \\
\hline [16] & India & $\begin{array}{l}\text { Titanium } \\
\text { Oxide }\left(\mathrm{TiO}_{2}\right) \\
\text { Nanoparticles, } \\
\text { RHA, OPC, }\end{array}$ & $\begin{array}{l}\text { Titanium Oxide }\left(\mathrm{TiO}_{2}\right) \text { used } \\
(0 \% \text { to } 5 \%) \text { and } \mathrm{RHA}(10 \%) \\
\text { as partial replacement of } \\
\mathrm{OPC}\left(\mathrm{G}_{\mathrm{s}}=3.15\right) \text {, Curing ages } \\
\text { at } 7,28 \text { and } 90 \text { days. }\end{array}$ & $\begin{array}{l}\text { Increase in } \\
\text { compressive, flexural } \\
\text { and splitting tensile } \\
\text { strength by } \\
\text { incorporating only } \\
10 \% \text { RHA with OPC. }\end{array}$ & $\begin{array}{l}\text { The highest } \\
\text { performances in } \\
\text { terms of strength } \\
\text { and durability } \\
\text { have been } \\
\text { revealed at an } \\
\text { incorporation of } \\
10 \% \text { RHA and } 3 \% \\
\mathrm{TiO}_{2} \\
\mathrm{Nanoparticles.} \\
\text { Slight strength } \\
\text { reduction was } \\
\text { noticed after } 7 \\
\text { days curing age. } \\
(\mathrm{OPC}-\mathrm{RHA} \text { - Nano } \\
\text { TiO }{ }_{2} \text { ) cementitious } \\
\text { system has } \\
\text { improved strength } \\
\text { and has capacity } \\
\text { to reducen } \\
\text { permeability and } \\
\text { resistance to } \\
\text { deterioration by } \\
\text { hydrochloric acid. }\end{array}$ \\
\hline [17] & India & $\begin{array}{l}\text { RHA (Rice } \\
\text { Hush Ash), } \\
\text { Green } \\
\text { Concrete, }\end{array}$ & $\begin{array}{l}\text { RHA (Rice Hush Ash), } \\
\text { Green Concrete, OPC, } \\
\text { Curing ages } 7,14,28 \text {, etc. }\end{array}$ & $\begin{array}{l}\text { If the amount of RHA } \\
\text { is } 20 \% \text { it can improve } \\
\text { the compressive } \\
\text { strength. If the } \\
\text { amount of } \mathrm{RHA} \\
\text { substitution is }\end{array}$ & $\begin{array}{l}\text { In the light of this } \\
\text { review paper it is } \\
\text { found that the } \\
\text { quality of rice husk } \\
\text { ash is dependent } \\
\text { on many factors }\end{array}$ \\
\hline
\end{tabular}


increased from $5 \%$ to $15 \%$ the resistance to splitting tensile strength, abrasion and flexural strength will increase gradually.

\section{[18] USA}

\author{
RHA (Rice \\ Hush Ash) as \\ SCM \\ (Supplementar \\ $y$ \\ Cementitious \\ Material), OPC \\ ASTM Type I \\ $10 \%$ and $20 \%$, \\ Class C Fly \\ Ash (FA)
}

OPC $\left(G_{s}=3.15\right), R H A$ of 3

different sizes $(600 \mu \mathrm{m}, 150$

$\mu \mathrm{m}$, and $44 \mu \mathrm{m}$ ) with $10 \%$

and $20 \%$ were incorporated,

Fly Ash (FA), ASR tests

conducted, One-Way

ANOVA method was

suggested.

\section{Finer RHA-3 \\ presented the \\ enhanced}

performance as per

the results of the ASR

and deicing chemical

tests.

Coarse RHAs (RHA-1 and RHA-2) exhibited remarkable strength

reduction in conventional concrete.

Thus, Finer RHA-3

can be utilized as

supplementary

cementitious material

especially with $10 \%$

replacement by wt. of

cement.

\author{
such as source \\ from where the \\ rice husk is \\ gathered, time and \\ temperature of its \\ burning, \\ incineration \\ method. It can be \\ utilized as a \\ cementitious \\ material. \\ Finer RHA and \\ CFA modified \\ concrete showed \\ the improved \\ workability and \\ strength properties \\ than the coarser \\ RHA modified \\ concrete.
}

\section{Discussion on Previous Findings}

Additional cementitious materials are being used to enhance the properties of fresh and hardened concrete. Rice Husk Ash is one of such materials but is still not fully applicable in the construction industry. The above mentioned researches and studies Table 1 tried to investigate the effects of RHA on the different properties of fresh and hardened concrete. In a study when cement was replaced by RHA having specific gravity of 1.89 in proportions of $20 \%$ to $50 \%$ the effect on compressive strength was not enough but at later ages of 60 days curing at $20 \%$ inclusion of GRHA having specific gravity of 2.24 it was improved and at 50\% incorporation of GRHA the resistance to chloride penetration increases and steel corrosion reduces (Rattanachu et al. 2020). In another study when the cement was incorporated with the GRHA by $20 \%$ and $35 \%$ the results exhibited the strength enhancement (Jongpradist et al. 2018). RHA is compatible with CEM II B-LL 32.5 R cement [14] and it has been revealed that the material has good mechanical behaviour in terms of compression and tensile and thermal characteristics. The RHA has good shear performance and the punching-bending test proved that the inter joists are very strong. The study also exhibits that the RHA composite could be used load bearing walls, partitions, false ceilings and inter joists (Chabi et al. 2020).

In case of replacing sand with recycled waste glass powder various tests were conducted on the hardened concrete to find out the compressive strength, split tensile strength and modulus of elasticity of concrete. No major change found in compressive strength of mix. The split tensile strength value decreases with increase in replacement proportions [4]. If the source of glass waste is lighting material the microscopic analysis showed the flat shape causing the accumulation of air beneath the grains in the concrete mix (Drzymała, Zegardło, and Tofilo 2020). In case of CRT glass the densities increases because of low water absorption (Song et al. 2019). The workability of fresh concrete decreases in case of discarded beverage glass due to sharp edges (Bisht and Ramana 2018), but when Metakaolin is used as a cementitious material and CRT glass is incorporated the flow ability is increased (Ouldkhaoua et al. 2020).

\subsection{Physical Physical and Chemical characteristics of RHA}




\subsubsection{Physical and Chemical Properties of Rice Husk Ash (RHA):}

Hard protecting coverings of the rice grains are known as rice husks.

Table 2 : The chemical composition of Ground Rice Husk Ash (GRHA) and ordinary Portland cement (OPC)

\begin{tabular}{lcc}
\hline Chemical Composition $(\%)$ & Ordinary Portland Cement & Grounded Rice Husk Ash \\
\hline Aluminum Oxide $\left(\mathrm{Al}_{2} \mathrm{O}_{3}\right)$ & 4.8 & 0.2 \\
Silicon Dioxide $\left(\mathrm{SiO}_{2}\right)$ & 20.9 & 93.5 \\
Calcium Oxide $(\mathrm{CaO})$ & 65.4 & 0.9 \\
Iron Oxide $\left(\mathrm{Fe}_{2} \mathrm{O}_{3}\right)$ & 3.4 & 0.4 \\
Sulfur Trioxide $\left(\mathrm{SO}_{3}\right)$ & 2.65 & 0.3 \\
Magnesium Oxide $(\mathrm{MgO})$ & 1.3 & 0.5 \\
Sodium Oxide $\left(\mathrm{NaO}_{2}\right)$ & 0.3 & - \\
Potassium Oxide $\left(\mathrm{K}_{2} \mathrm{O}\right)$ & 0.4 & 3.4 \\
Loss on Ignition $(\mathrm{LOI})$ & 1.1 & 8.6 \\
\hline
\end{tabular}

\subsubsection{Alkali-silica reaction (ASR)}

Alkali-silica reaction (ASR) is broadly known as "Concrete Cancer" is an injurious swelling reaction that takes place in the concrete mix containing the alkaline cement paste and the reactive amorphous silica which is mostly present in the moist aggregates with the passage of time. The ASR cause cracking, spalling and reduce the strength of concrete. It is observed that the expansion due to ASR increases with increase in CRTG (Duggal 2008). The highest expansion observed at 28 days curing with $50 \%$ replacement as shown in Figure 1.The increase in ASR expansion is due to the presence of higher $\mathrm{SIO}_{2} / \mathrm{CaO}$ ratio (Food and Agriculture Organization of the United Nations 2018). The incorporation of MK up to $10 \%$ and $15 \%$ was still within the prescribed limit of $0.1 \%$, this is because of the pozzolanic reaction which minimizes the $\mathrm{SiO}_{2} / \mathrm{CaO}$ ratio.

b) $10 \mathrm{MK}+\mathrm{CRTG}$

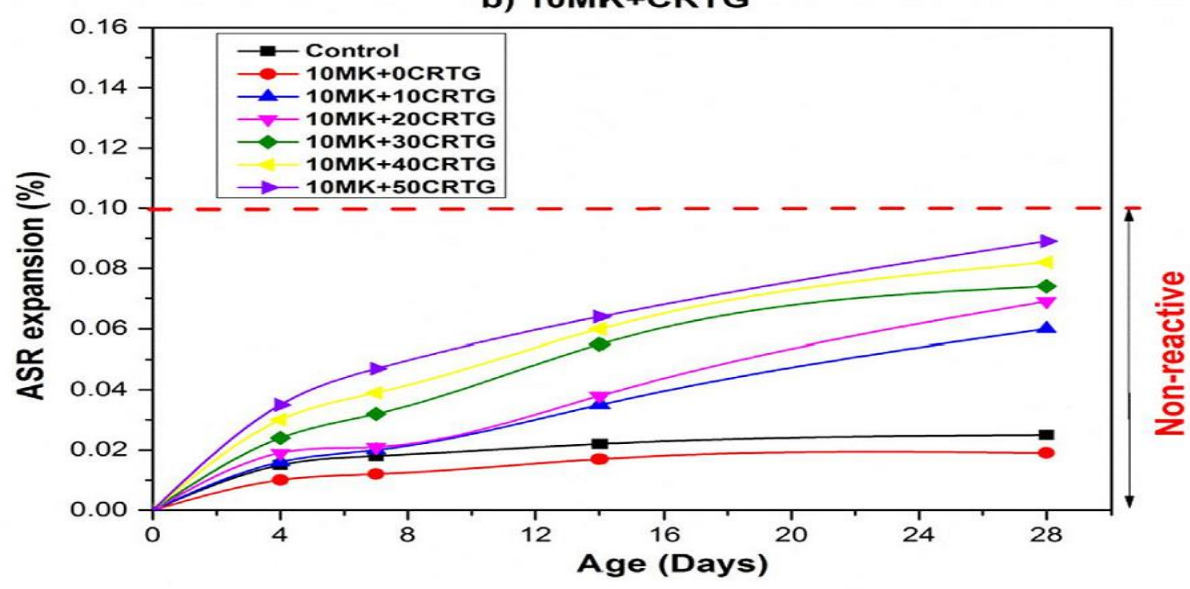

Figure $4:$ The expansion due to ASR in the concrete [9]

\section{Conclusion}

This study The utilization of Rice husk ash as a cementitious material and recycle waste glass as fine aggregate in the construction and infrastructure industry offers an energy saving, environmentally friendly and sustainable alternatives to the cement and natural sand.

Upon reviewing the published literature on RHA and Recycled Waste Glass utilized in concrete, the following conclusions can be drawn: 
The RHA is utilized as a partial cementitious material in the normal, self compacting and high strength concrete and it proved low shrinkage and permeability, high strength, high resistance to carbonation, sulphate, and acid attack.

The grinding time of RHA depends upon the source from where you accumulate it but minimum recommended mechanical grinding time is around 30 minutes to get desirable properties of ash.

The chemical composition of RHA varies it is dependent on the incineration process. It contains high amorphous reactive silica the desirable percentages of amorphous silica can be obtained by fully controlled incineration of RHA that is around 7000C.

The proper mechanical grinding of RHA for finer particles can enhance the properties and those properties play an important role for the pozzolanic reaction with other cementitious materials. That grinding time is around 30 minutes for desirable results.

It is proved that the untreated rice husk is compatible with CEM II B-LL $32.5 \mathrm{R}$ cement. It has good thermal characteristics and shear performance.

The proper curing is essential for the density, microstructure and strength of concrete. The higher age curing such as 28 days and beyond develop a high pozzolanic reactivity and boost the formation of additional C-S-H gels.

From the analysis of above mentioned researches it is revealed that the replacement level of RHA should be around $30 \%$ to $35 \%$ with lesser size particles up to $20 \mu \mathrm{m}$ because at higher levels of replacement, the strength reduced due to presence of voids. At $30 \%$ replacement the mix will be denser and there will be reduction in water absorption.

The analysis and study of the previous different research articles in which the recycled waste glass is used as substitute to the natural sand as fine aggregate evaluated the following main findings.

Because of the similarity in the chemical composition and physical structure of the recycled waste glass powder we found no significant discrepancy in the mechanical properties of the concrete after adding different proportions of the recycles waste glass as an alternative to the natural sand.

The different tests were conducted on the hardened concrete to find out the compressive strength (IS 516-1959), split tensile strength (IS 5816-1999) and modulus of elasticity (IS: 516 - 1959) of concrete. No major change found in compressive strength by replacing sand with recycled waste glass powder. The split tensile strength value decreases with increase in replacement proportions.

The apparent strong point of using the recycled glass powder is the negligible water absorption capacity, which causes no change in the workability.

It is found that recycled tube light waste glass can be used as coarse aggregate in the concrete. A mixture containing $30 \%$ by weight has parameters that make it feasible as a construction material.

In case of CRT waste glass used as replacement of fine sand it was evaluated that the hardened density, water absorption and damping ratio would decrease when max: particle size is minimized from $0.45 \mathrm{~mm}$ to $0.60 \mathrm{~mm}$ on the other hand the compressive strength, tensile strength and elastic modulus and UPV would decrease.

When 50\% inclusion of CRTG as fine aggregate and 10\% Metakaolin as cementitious material is used the increase in workability, UPV and compressive strength in concrete mix is observed. The chloride ion permeability resistance is observed much higher. It is proved that the MK and CRTG are beneficial for durability. The SEM analysis indicated that the incorporation of MK and CRTG up to $15 \%$ can increase porosity due to pozzolanic effect of MK cementitious material which assists in hydration process.

In case of discarded beverage glass, the compressive strength has no substantial growth but was noticed at inclusion of $21 \%$ and it was noticed that flexural strength and water absorption increases and bulk density of the concrete mix decreases.

\section{Gape of Study}

This review covered the current practice and guidelines of RHA-blended concrete. Simultaneously, this review also revealed a gap in in-depth investigations about the long-term durability and serviceability of reinforced RHA-blended concrete.

It was observed that limited research has been done on waste glass as coarse aggregate (Tube light glass).

It causes damage to the vehicle tires when used in the rigid pavements. Tube light glass has phosphor which is harmful to the environment and cause damage to the skin.

There should be a study in which recycled waste glass should be used in both forms as fine and coarse aggregate. 
Seismic performance of the structures made up with the partial replacement of recycled glass waste and rice husk ash should be studied.

The findings of previous studies shows that the use of RHA as cement replacement is for normal strength concrete mixes but there is a need of detailed study especially on high strength concrete mix by utilization of RHA and its durability and other parameters should also be investigated in the aggressive environment.

The impact of seawater on the performance of concrete incorporated with partial replacement of cement with rice husk ash and recycled waste glass as fine aggregate.

\section{References}

Anand, Alina, and Shahas S. 2015. "Effect of Recycled Glass Powder as Fine Aggregate on the Mechanical Properties of Concrete." IJERT 3(29):1-4.

Bisht, Kunal, and P. V. Ramana. 2018. "Sustainable Production of Concrete Containing Discarded Beverage Glass as Fine Aggregate." Construction and Building Materials 177:116-24. doi: 10.1016/j.conbuildmat.2018.05.119.

Chabi, Edem, Valéry Doko, Sena Peace Hounkpè, and Edmond C. Adjovi. 2020. "Study of Cement Composites on Addition of Rice Husk." Case Studies in Construction Materials 12:e00345. doi: 10.1016/j.cscm.2020.e00345.

Datis Export Group. 2020. "Worldwide Cement Production From 2015 to 2019." Datis Export Group. Retrieved February 4, 2021 (https://datis-inc.com/blog/worldwide-cement-production-from-2015to-2019/).

Drzymała, Tomasz, Bartosz Zegardło, and Piotr Tofilo. 2020. "Properties of Concrete Containing Recycled Glass Aggregates Produced of Exploded Lighting Materials." Materials 13(1):1-16. doi: $10.3390 / \mathrm{ma13010226.}$

Duggal, S. K. 2008. Building Material. 3rd ed. New Delhi: New AGE International Publisher.

Food and Agriculture Organization of the United Nations. 2018. "EST: Rice Market Monitor (RMM)." Food and Agriculture Organization of the United Nations. Retrieved February 4, 2021 (http://www.fao.org/economic/est/publications/rice-publications/rice-market-monitor-rmm/en/).

IEA. 2017. "Energy Technology Perspectives 2017." IEA. Retrieved February 4, 2021 (https://www.iea.org/reports/energy-technology-perspectives-2017).

Jongpradist, Pornkasem, Watee Homtragoon, Raksiri Sukkarak, Warat Kongkitkul, and Pitthaya Jamsawang. 2018. "Efficiency of Rice Husk Ash as Cementitious Material in High-Strength Cement-Admixed Clay." Advances in Civil Engineering 2018:1-11. doi: 10.1155/2018/8346319.

Morrin, Noel. 2003. Sustainability Initiative. Vol. 34. Washington, D.C.

Ouldkhaoua, Younes, Benchaa Benabed, Rajab Abousnina, El-Hadj Kadri, and Jamal Khatib. 2020. "Effect of Using Metakaolin as Supplementary Cementitious Material and Recycled CRT Funnel Glass as Fine Aggregate on the Durability of Green Self-Compacting Concrete." Construction and Building Materials 235:117802. doi: 10.1016/j.conbuildmat.2019.117802.

Rattanachu, Pokpong, Prajak Toolkasikorn, Weerachart Tangchirapat, Prinya Chindaprasirt, and Chai Jaturapitakkul. 2020. "Performance of Recycled Aggregate Concrete with Rice Husk Ash as Cement Binder." Cement and Concrete Composites 108:103533. doi: 10.1016/j.cemconcomp.2020.103533.

Song, Wen, Dujian Zou, Tiejun Liu, Jun Teng, and Lei Li. 2019. "Effects of Recycled CRT Glass Fine Aggregate Size and Content on Mechanical and Damping Properties of Concrete." Construction and Building Materials 202:332-40. doi: 10.1016/j.conbuildmat.2019.01.033. 